\title{
Decentralization of Foreign Cooperation: Case Study of Sister Province Cooperation between West Java, Indonesia and South Australia

\author{
Desentralisasi Kerja Sama Luar Negeri: Studi Kasus Kerja Sama Antara \\ Pemerintah Provinsi Jawa Barat, Indonesia dan Australia Selatan
}

\author{
Andriani Florencia Dharmajaya*, Anggara Raharyo* \\ *President University, Lecturer of International relations of President University \\ email: andrianiflorenciaa@gmail.com, anggara.raharyo@president.ac.id
}

\section{Riwayat Artikel}

Diterima 9 Maret 2019

Direvisi 8 April 2019

Disetujui 2 Mei 2019

\begin{abstract}
Cooperation between cities and states/provinces has gained its attention in contemporary global affairs. Most scholars refer to it as para-diplomacy, which can be defined as cooperation between sub-national actors for the benefit or the interest of the national governments. This research focuses on the practice of para-diplomacy between West Java Province of Indonesia and South Australia. It aims to explain the progress of the sister province cooperation out of the renewal of its agreement in 2015 and their progress of cooperation until 2017. This research utilizes annual reports of the cooperation from both sides of the parties to identify the practices and progress of the cooperation. From the analysis, cooperation in agriculture, fisheries, and tourism, including culture and education are still in the developing progress. Nevertheless, several sectors have shown an improvement on the West Java's side.
\end{abstract}

Keywords: Para-diplomacy; West Java; South Australia; Indonesia - Australia, Sister Province.

\begin{abstract}
Abstrak
Kerja sama antar Pemerintah Kota dan Pemerintah Provinsi telah menjadi salah satu perhatian di studi Hubungan Internasional. Mayoritas peneliti menamakan hal ini sebagai aktivitas paradiplomasi yang berarti kerja sama yang dilakukan oleh aktor sub-nasional untuk mendapatkan manfaat atau mencapai kepentingan nasional. Penelitian ini berfokus pada praktik paradiplomasi antara Pemerintah Provinsi Jawa Barat dengan Australia Selatan. Penelitian ini bertujuan untuk menjelaskan perkembangan dari kerja sama provinsi yang telah dilaksanakan dari pembaharuan perjanjian kerja sama pada tahun 2015 hingga tahun 2017. Penelitian ini menggunakan laporan tahunan dari kedua belah pihak sebagai sumber utama. Dari analisis ini, kerja sama dalam bidang pertanian, perikanan, dan pariwisata serta kebudayaan dan pendidikan masih dalam tahap perkembangan awal. Walaupun, beberapa sektor telah menunjukkan perkembangan yang baik, terutama bagi Jawa Barat.
\end{abstract}

Kata Kunci: Paradiplomasi; Jawa Barat; Australia Selatan; Indonesia - Australia; Sister Province. 


\section{Background}

The cooperation between cities and states/provinces has gained its attention in contemporary global affairs. Most scholars refer it as para-diplomacy, where it could be defined as the cooperation which could be done by the sub-national actor in order to gain the benefit or reach the interest of the national government. ${ }^{1}$ Through para-diplomacy, the sub-national actor could involve in international affairs and could reach the national interests from its involvement in international affairs. The concept was established in Europe at the post-second world warglobal circumstances. ${ }^{2}$ The first idea behind the establishment of para-diplomacy is because of the local government was finding a solution forglobal peace. Nowadays, within the development of globalization and the need every region to internationalize their region in international affairs, the concept is spread all over the world, also no exception in Indonesia. The practice of para-diplomacy in Indonesia supported by the statement of President Susilo Bambang Yudhoyono. In 2010, at the meeting of Australia's Businessmen in Canberra, President invited them to make a relation bydirectly contact to the local government both regency/city and province, including the Governor in Indonesia for doing the investment in Indonesia. ${ }^{3}$

One of the authorities that given to the local government is framed under the Law (undangundang) no. 22 of 1999 about local government, where the law ruled about the local government that could do the cooperation with foreign parties. In article 88 , stated that regions could conduct mutually beneficial cooperation with foreign institutions or agencies, which are

1 Marten Kooistra, Paradiplomacy in Practise: The Development of Paradiplomacy in Quebec, Scotland, and Califormia (2017), 3

2 Rakhahari Chatterji and SwagataSaha, "Paradiplomacy: Concept and the Context," India Quarterly (2017): 376

3 Takdir Ali Mukti, Paradiplomacy: Kerjasama Luar Negeri oleh Pemda di Indonesia (Yogyakarta: The Phinisi Press, 2013), 2 governed by joint decisions. ${ }^{4}$ The law becomes the cornerstone for the local government to have the authority in conducting cooperation with the foreign parties. Strengthened by law article 18 about the duties and authority of the Regional House of Representatives, where it is stated that one of the duties of the House of Representatives is to provide opinions and considerations to the Government regarding the plan of an international treaty that related with the regional interests. Also, the law no.32 of 2004 Article 42 also explain about the duties of the Regional House of Representatives.

The local government who conduct the cooperation with foreign parties needs to discuss and receive the recommendation from the Ministry of Foreign Affairs as well as the Ministry of Home Affairs as well as the related institution. ${ }^{5}$ Next, the local government together with the Ministry of Foreign Affairs conduct the exploratory via the Indonesian representative in that country to see the possibility and potential to do the cooperation with the foreign parties, including the local government at a foreign country.

According to the cooperation with the foreign parties, every region has the same authority to do the cooperation with foreign parties, not exclude West Java Province. West Java has started their sister province cooperation with South Australia which started in $1997 .{ }^{6}$ In 2015, they revitalized their MoU for sister province cooperation. The signing of the revitalized $\mathrm{MoU}$ was done in the Adelaide Festival Center on September 24, 2015, by the Vice Governor of West Java, Deddy Mizwar and the South Australian Premier, Jay

4 Indonesia, Kementerian Sekretariat Negara Republik Indonesia, Undang-undang Republik Indonesia Nomor 22 Tahun 1999, Jakarta: 1999.

5 Kementerian Luar Negeri Direktorat Perjanjian Ekonomi dan Sosial-Budaya, Panduan Umum Tata Cara Hubungan dan Kerjasama Luar Negeri oleh Pemerintah Daerah (Jakarta: 2006), 26

6 Masaki Minami, The Role and Policy of the South Australian Government in the Development of Economic Ties with Asian Nations (Adelaide: 1997), 42 
Weatherill. The signing also companied by the Consul General Yayan Mulyana and also the Governor of South Australia. ${ }^{7}$

In the $\mathrm{MoU}$, there are six areas that are included in the cooperation, which are: agriculture, tourism, education, health, government, and promotion and facilitation of commercial opportunities. ${ }^{8}$ In implementing the MoU, both parties could make the working group, which the function of the group is to manage to the plan and work programs of the MoU. The working group responsible to evaluate activities that have been conducted as well as giving recommendation for the next programs and activities. The working group's members consist of the selected government officials or the selected private sector representatives. In here, the working group could conduct the annual meetings when it is necessary, where the meeting could be conducted in Bandung or Adelaide. The duration of the $\mathrm{MoU}$ would be 5 years and both parties could extend the period for one or more period.

This research focuses on the practice of para-diplomacy between West Java Province of Indonesia and South Australia. It aims to explain the progress of the sister province cooperation that renewed its agreement in 2015 and their progress of cooperation until 2017. This research utilizes annual reports of the cooperation from both sides of the party to identify the practice and progress of the cooperation. The first part of this research will analyze factors that influence the cooperation between both parties, it then will analyze

7 KJRI Sydney, "Signing of MoU on Sister Province / State Cooperation between West Java and South Australia," KJRI Sydney, 24 September 2015, accessed February 20, 2019, https://www.kemlu.go.id/sydney/ en/berita-agenda/berita-perwakilan/Pages/Signing-ofMoU-on-Sister-Province-State-Cooperation-betweenWest-Java-and-South-Australia.aspx

8 Government West Java and South Australia, Memorandum of Understanding Between the Government of West Java Province of the Republic of Indonesia and The Crown in Right of the State of South Australia Concerning Sister Province - State Cooperation (Adelaide: 2015). the practice and progress of the cooperation conclusion in the final part.

\section{Para-diplomacy}

According to Andre Lecours, paradiplomacy, as conducted by the sub-state governments in developed societies, can have many different focuses where not all regional governments have approached international relations in a similar way thus divided paradiplomacy into several layers. ${ }^{9}$ First, the relation and cooperation of the sub-state which the orientation only in the scope of economic issues where the aims of the cooperation related with the economic matters such as attracting foreign markets, enlarging the number of investors, and explore for the new exports markets. In the layer of economic issues, there is no explicit to the political dimension, and also nor to the cultural issues which will be included in the cooperation. The second layer consists of the multidimensional where the para-diplomacy not only limited to one sector, but it consists of many sectors such as cultural, educational, technical, technological, and so on. The third layer is the complex layer where the political matters are involved in the para-diplomacy. Para-diplomacies in the third layer belong to the country who develop the international relations ambitiously in order to express their specific national identity and they're autonomous which differs from most of the regions in their state. In other word, they seek attention from other regions in other countries and to influence their neighborhood regions' behavior.

In practice the para-diplomacy, there are several steps which need to be fulfilled by the local government. According to Rodrigo Tavares, the first step is the establishment of umbrella foreign affairs policy, which as known as White Papers or government plans thus will become the guide in achieving the goals

9 Andre Lecours, Political Issues of Paradiplomacy: Lessons from the Developed World (Netherlands Institute of International Relations 'Clingendael', 2008), 3 
of the project. ${ }^{10}$ Following the guidance, the local government needs to distinguish between programs, projects, and actions where it will help the local government in managing the project. Furthermore, in preparing and managing the project, there are five components which need to be fulfilled, those are:initiation, planning and design, execution and construction, monitoring and controlling systems, and completion. ${ }^{11}$

\section{Internal and External Factors}

In the practice of para-diplomacy, there are internal and external factors which could boost the initiation of the cooperation of local government with the foreign parties. In the case of the sister province cooperation in West Java, the internal factors come from the potentials inside West Java Province.In here, the author focuseson three main sectors, which are agriculture, fishery, and tourism including culture and education. Meanwhile, the external factor comes from the diplomatic relationship between Indonesia - Australia.

\section{Agriculture in West Java}

West Java is one of the provinces in Indonesia that has a fairly extensive of land for agriculture, where it could become a big potential for the national food. There is three biggest potentials of agriculture in West Java, which are rice, corns, and soybeans. ${ }^{12}$ Gedong Gincu mango is one of the local products from West Java that entered the foreign market. There are a lot of countries that import this kind of mango from this province, which are Singapore, Japan, Korea, and the Middle East. Based on the interview that showed in the article, one of the farmers of this mango stated

10 Rodrigo Tavares, Paradiplomacy: Cities and States as Global Players (New York: Oxford University Press, 2016), 120

11 Ibid.

12 Zuli Istiqomah, "Jabar Potensi Kedaulatan Pangan Nasional,” Republika.co.id, 23 January 2017, accessed February 20, 2019, https://www.republika.co.id/ berita/nasional/daerah/17/01/22/ok6nwg370-jabarpotensi-kedaulatan-pangan-nasional. that the product of Gedong Gincu mango from Majalengka, West Java has a high in quality and it makes this mango is attractive to be imported. ${ }^{13}$ Gedong Gincu mango with the export quality has a higher price rather than the normal quality, where the range of the price is from 50,000 rupiah to 100,000 rupiah per kilograms. ${ }^{14}$

\section{Fisheries in West Java}

There are many provinces in Indonesia that could support the development of the fisheries sector. West Java is one of them with the big opportunities and potentials in supporting this sector. The Vice Governor of West Java Province during period 2013 - 2015, Deddy Mizwar, currently the potentials in fisheries sector of this province still cannot be maximized. ${ }^{15}$ This comes from the yearly report in 2016, where from this report could get data that the production of fisheries in West Java are 276.000 ton, increased about 1.95 percent compared with the production in 2015. ${ }^{16}$ Meanwhile, the production is increasing from 2015 to 2016 but, the increaseis only about 13.35 percent from all of the fisheries potentials that this province had. ${ }^{17}$

Tourism, including Culture and Education in West Java

According to the Chairperson of Indonesian Chamber of Commerce and Industry in West Java region, Agung Suryamal, there are 309 potentials of tourist destination in this province,

13 Yudha Manggala P Putra, "Mangga Gedong Gincu Diminati Pasar Timur Tengah," Republika.co.id, 5 May 2014, accessed February 20, 2019, https:// www.republika.co.id/berita/nasional/jawa-baratnasional/14/05/05/n53 prj-mangga-gedong-gincudiminati-pasar-timur-tengah.

14 Ibid.

15 Tempo.co, "Deddy Mizwar: Potensi Perikanan Jabar Belum Optimal,” Tempo.co, 17 December 2017, accessed February 20, 2019, https://nasional.tempo. $\mathrm{co} / \mathrm{read} / 1043043 /$ deddy-mizwar-potensi-perikananjabar-belum-optimal.

16 Ibid.

17 Ibid. 
but the government still not maximize all of the potentials that could be impact positively to the regional economy. ${ }^{18}$ Agung Suryamal also stated the high potential of tourism in West Java, around 60 percent the development still not maximized that cause by the limit of infrastructure. On the other hand, West Java Province also has a lot of arts and cultures. The culture of West Java is dominated by Sundanese culture. The uniqueness of the culture could be a characteristic for the province. The local government is put more effort and focus on maintaining the culture of this province. ${ }^{19}$ To continue the conservation of culture in this province, the local government in West Java choose several villages in this province to being set as the culture village, which could be managed as a place to conserve the culture in the form of culture house that becomes as one of the identities of this province.

Moreover, the quality of education in West Java also need to be improve. ${ }^{20}$ The quality of the teachers is very important for the quality of the education, where it is very impactful to the result of the education of the students. According to the statement of the regional secretary of Bandung, Yossi Irianto, to improve the quality of the education, it needs to organize the equitable education for the better quality of education as well as improve the educational facilities and infrastructure. ${ }^{21}$ On the other hand, to improve the quality of education, not only limited to the improvement

18 Astri Agustina, "Pengembangan pariwisata di Jawa Barat belum maksimal," Merdeka.com, 1 August 2018, accessed February 20, 2019, https://bandung. merdeka.com/pariwisata/pengembangan-pariwisata-dijawa-barat-belum-maksimal-180801t.html.

19 Pemerintah Provinsi Jawa Barat, "Potensi Seni dan Budaya Jawa Barat", Pemerintah Provinsi Jawa Barat, 2006, accessed February 20, 2019, http:// www.jabarprov.go.id/index.php/potensi_daerah/ detail/20/4

20 Pemerintah Provinsi Jawa Barat, "6 Misi Tingkatkan Kualitas Pendidikan,” Pemerintah Provinsi Jawa Barat, 29 March 2017, accessed February 20, 2019, http://www.jabarprov.go.id/index.php/ news/22180/2017/03/29/6-Misi-TingkatkanKualitas-Pendidikan.

21 Ibid. of the quality of the teachers but also need to improve the character building of the society and support from the government in order to improve the quality of education for fulfilling the employment needs.

\section{Indonesia - Australia Bilateral Relations}

In describing the relation between Indonesia and Australia, according to the former Indonesian Consul General in Sydney, Yayan GH Mulyana, describe this relation with the Indonesian song titled "Benci tapi Rindu" or hate-love relationship. ${ }^{22}$ The relation between both countries could be described with that title because of both countries have ups and downs in this relation. This relation has been establish since the independence of Indonesia, where in that occasion Australia is one of countries that give the political support and acknowledge the sovereignty of Indonesia after its independence. ${ }^{23}$ One of the cooperation of Indonesia and Australia is the Joint Declaration on Comprehensive Partnership between Australia and the Republic of Indonesia signed by the Australian Prime Minister and Indonesian President in Canberra onApril 2005. Both Australia and Indonesia agreed to commit with this cooperation in order to gain a peaceful situation and condition, as well as prosperous in Indo - Pacific Region, where here both of them are put ASEAN as the central of its vision, and respect the rights of all states, and based on the international rules and norms. ${ }^{24}$

22 Guzrizal Dt Salubuak Basa, "Bridging the Gap Between Indonesia and Australia," Australian Institute of International Affairs, 28 May 2018, accessed February 20, 2019, https://www.internationalaffairs.org.au/ australianoutlook/bridging-the-gap-between-indonesiaand-australia/.

23 Australian Government Department of Foreign Affairs and Trade, "Joint Declaration on a Comprehensive Strategic Partnership between Australia and Republic of Indonesia," Australian Government Department of Foreign Affairs and Trade, 31 August 2018, accessed February 20, 2019, https://dfat.gov.au/geo/indonesia/Pages/ joint-declaration-comprehensive-strategic-partnershipbetween-the-commonwealth-of-australia-and-republicof-indonesia.aspx. 
By doing this, both of them could open markets that lead to the free flow of trade, capital and ideas where it makes both parties could work closely that provide the strengths and opportunities for both countries in benefit for the peoples by giving contributes in give the resolution of traditional and traditional treats as well as the challenges infacing them and the future of those treats. Besides that, this partnership also opens opportunities for Australia and Indonesia to strengthen their trade, investment, and also business relations. From here, it could boost the relation in cultures and communities and make links between people to people from both countries.

\section{Analysis}

Based on the research and analysis regarding the para-diplomacy in Indonesia based on the three layers of para-diplomacy by Andre Lecours, the practice of para-diplomacy in Indonesia both in province or Regency/city could be described by the type of para-diplomacy in the second layer. ${ }^{25}$ The cooperation in the second layer of para-diplomacy is not limited to only one sector, but it consists ofmany sectors. Same with the cooperation of the sister province cooperation between West Java and South Australia which consists of many sectors, thus proved the second layer of paradiplomacy is the most suitable in describing the type of Indonesia's para-diplomacy. Most of the relations and cooperation which made by the local government in Indonesia are using the MoU as the legal document of the existence of the cooperation between local government with the foreign parties, where both parties cooperate in many sectors.

According to Tavares, there are steps which should be fulfilled by the local government as well as the foreign parties in conducting the para-diplomacy, which are initiation, planning and design, execution and construction, monitoring and controlling systems, and completion. ${ }^{26}$ From the first step, initiation, there is discussion and preparation which had been done by both parties. Few years before the signing of $\mathrm{MoU}$, both parties had visited each other in order to discuss and find the potentials which could be developed as well as included in the cooperation. From several visits, it comes up to the making of $\mathrm{MoU}$ which had been signing in 2015. Following with the signing of $\mathrm{MoU}$, both parties arranged the joint working group as the group who responsible and manage for the planning and implementation of the cooperation. As the start of the cooperation, the joint working group conducts a meeting in order to arrange for the work plan and cooperation planning. In here, the joint working group set the programs for every sector which included in the cooperation.

The nextstep is execution and construction, where the programs had been running and implementing by both parties. The working plan of sister province cooperation between West Java and South Australia which had been conducted and implemented still need to be monitoring and controlling by the responsible parties which join in the programs. From there, it could be seen how the progress of the programs as well as the evaluation which need in order to maximize and improve the programs. The last step in conducting the para-diplomacy is the completion. The sister province cooperation between West Java and South Australia cannot be said complete, since the cooperation is still running until 2020.

Based on the guidance for the local governmentin conducting the cooperation with the foreign parties, the Provincial Government of West Java had conducted the sister province cooperation with South Australia based on it. In the making process of the cooperation, West Java also doing the communication and discussion with the Indonesian Consulate in 26 Ibid. no. 10 


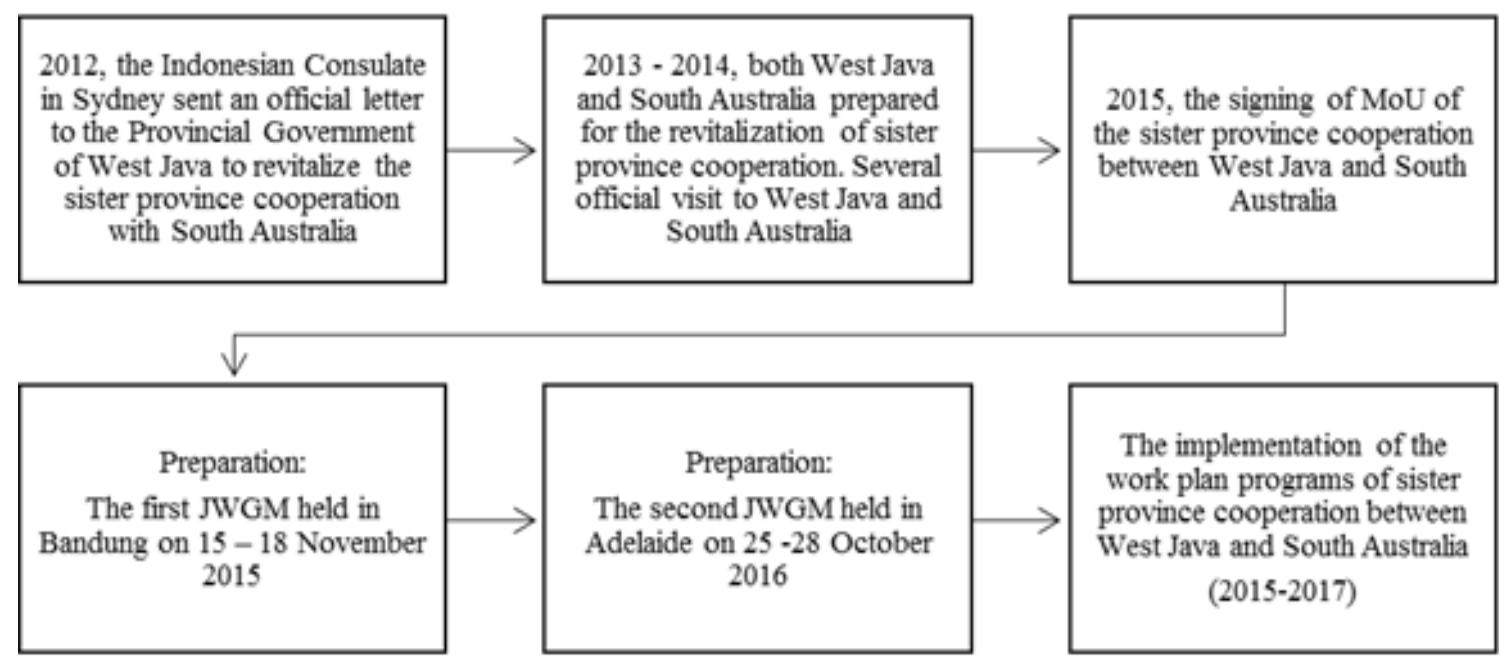

Graphic 1. The path of sister province cooperation between West Java and South Australia constructed by the writer from the annual report of the cooperation

Sydney regarding the potentials and the future of the sister province itself. The next step, the representative of both West Java and South Australia conduct the first meeting in order to set and negotiate about the Lol. After the agreement of LoI, both parties could arrange the draft of MoU where it including the sectors which will be cooperated, the Joint Working Group, as well as the related agency which will be responsible with the working program. After the signing of MoU, the Joint Working Group could start to discuss the working plan as well as the implementation of the sister province cooperation through the working plan which had been set. During the process of the implementation, the Joint Working Group also need to conduct a meeting for the evaluation regarding the progress of the cooperation and the future planning of the implementation.

The twinning province cooperation between West Java and South Australia which has been agreed by both parties since September 2015 marked by the signing of MoU by both parties, is one of the examples of the implementation and the practice of Indonesia's para-diplomacy towards the sister province cooperation. In the sister province cooperation, the provincial government could conduct the cooperation in several sectors, such as trade and investment, education, agriculture, tourism, arts and culture, and so on. Based on the MoU which being signed by West Java and South Australia, the writer focus in three sectors included in this cooperation, which are agriculture, fisheries, and tourism including culture and education.

Since 2015 until 2017, there are several programs and agenda that has been done by West Java and South Australia. After the signing of MoU, both West Java and South Australia set the joint working group for this cooperation in order to manage and monitor the progress of this cooperation, as well as to give suggestion and evaluation regarding the progress and the report of the programs that have been doing by both parties. From 2015, there had been done several joint working group meeting (JWGM) in order to evaluate and discuss the future planning regarding the work plan of this cooperation. The first JWGM held in Bandung on 15 - 18 November 2015. According to the opening speech of Governor of West Java Province in the period of 2015 2018, Ahmad Heryawan, in the first meeting, the team of Joint Working Group from both parties has discussed regarding the work plan as the implementation of the MoU that has been arranged before. The work plan is consists of nine sectors, which are agriculture, 
fisheries, tourism, art and culture, education, government, industry and trade, investment, as well as health.

The second JWGM held in Adelaide on $25-28$ October 2016. Following with the result of the first meeting previously, the second meeting discusses about the progress as well as the evaluation of the cooperation after the first meeting and also to give the future plan and the suggestion for the betterment of the progress in the sister cooperation of West Java and South Australia. In the second meeting, both West Java and South Australia also discuss and identify regarding the future work plan that had been done before by them, as well as the plan to enlarging the cooperation in the sectors that included in the cooperation. The third JWGM held in Bandung and supposed to be in November 2017, but because of several conditions, it should be postponed.

As explained above are steps which had been fulfilled by the Provincial Government of West Java. West Java had been follow the guidance as well as the rules and regulation which set by the related Ministries who have authorization inorganize and monitor the cooperation of local government with the foreign parties. The future of the sister province itself could be seen from the implementation of the working plan which been set by the Joint Working Group, as well as the progress which been done by West Java and South Australia.

Table 1. The work plan of Sister Province between West Java and South Australia in Agriculture, Fisheries, and Tourism, including culture and education sector

\begin{tabular}{|c|c|}
\hline Field & Program activity \\
\hline Agriculture & $\begin{array}{l}\text { Agriculture cooperation including sharing of knowledge and technology and } \\
\text { provision of products and services: } \\
\text { - South Australia to share its knowledge and systems in regards to } \\
\text { horticultural management practices and quarantine and pest control } \\
\text { - West Java Government participation at the Royal Adelaide Show }\end{array}$ \\
\hline \multirow[t]{2}{*}{ Fisheries } & $\begin{array}{l}\text { - Internship for fisheries vocational schools graduates or young potential } \\
\text { fishermen and university postgraduates from West Java in South Australia's } \\
\text { fisheries industry } \\
\text { - South Australian government to share with West Java knowledge related } \\
\text { to the development of aquaculture industry (in particular abalone, lobster, } \\
\text { tuna, and others farming) }\end{array}$ \\
\hline & $\begin{array}{l}\text { - Two way tourism promotion and facilitation:Meeting between West Java } \\
\text { and South Australia tourism agencies to discuss and agree on activities } \\
\text { aimed at two way tourism promotion and tourism cooperation } \\
\text { - Arts and Culture exchanges } \\
\text { - Facilitation of education collaboration and exchanges at primary, } \\
\text { secondary, vocational and tertiary level through sister school relationships } \\
\text { and support in South Australia for teaching of Indonesian language in } \\
\text { South Australian government schools }\end{array}$ \\
\hline \multirow[t]{5}{*}{$\begin{array}{l}\text { Tourism, including } \\
\text { culture and } \\
\text { education }\end{array}$} & $\begin{array}{l}\text { - Proposed advisor of Indonesian language and culture to support teachers } \\
\text { of Indonesian language and culture in South Australian schools under } \\
\text { proposed MoU with Indonesian and the MECD }\end{array}$ \\
\hline & $\begin{array}{l}\text { - INDOfest schools program, for the development and presentation of } \\
\text { language and cultural related activities by students of Indonesian in South } \\
\text { Australia }\end{array}$ \\
\hline & - Proposed language teachers exchange (to and from Indonesia) \\
\hline & $\begin{array}{l}\text { - Proposed Reading Challenge program or activities exchange to encourage } \\
\text { reading students interest (in the frame of West Java Leader's Reading } \\
\text { Challenge / South Australia's Leader Reading Challenge) }\end{array}$ \\
\hline & - Short course for bankers from West Java in South Australia \\
\hline
\end{tabular}


Agriculture, fisheries, tourism including culture and education are three sectors which become the main focus in the sister cooperation between West Java and South Australia, where both parties have the potentials in enlarging and develop those sectors. In here, the writer would like to explain those sectors separately which is according to the work plan and implementing arrangement that have been set by the Joint Working Group.

\section{Agriculture}

Agriculture becomes one of the main focus sectors in the sister cooperation between West Java and South Australia. In this sector, there are several work plan that had been set by the Joint Working Group in order to develop and maximize the potential of agriculture sector in both region. As mentioned previously, West Java has a good potential in the agriculture sector. There are a lot of benefits that could be gain from this sector, including the development of regional economic. The agriculture products of West Java Province has a good position in the export market. Otherwise, in order to enter to the foreign market, the agriculture products from West Java need to increase its export quality.

Following with this, in the sister province cooperation with South Australia, West Java Province would like to enlarge the knowledge in the agriculture sector as well as to learn how to maximize the potential in the agriculture sector for the better quality of the products. One of the programs that has been set in the work plan is the sharing of knowledge and technology and provision of products and services, where in here South Australia will share its knowledge and systems towards the horticultural management practices and quarantine and pest control. ${ }^{27}$

27 Governmental and Cooperation Bureau of West Java Province, Achievement of the Implementation Sister Province - State Cooperation between West Java and South Australia (Bandung: 2017)
Regarding with the agricultural matters, West Java would like to get the sharing knowledge from South Australia about how to eradicate the fruit fly on the plant of Gedong Gincu Mango as well as mangosteens. West Java Province has a good potential within its Gedong Gincu Mango as well as the mangosteens, while the quality still not good enough for the export quality because of the fruit fly.Thus, it makes West Java would like to remove the fruit fly from the Gedong Gincu Mango as well as the mangosteens in order to maximize the export of those fruits to other countries.

According to the progress of the programs in the agriculture sector, the implementation of work plan in this sector still not yet running. The cause of the delay of the implementation in this sector is because of the lack of communications between the parties who responsible in this program, which are West Java Agency of Agriculture and Corps and West Java Agency of Fisheries and Marine/ Primary Industries and Regions South Australia (PIRSA). ${ }^{28}$ Otherwise, the need of West Java Province for this knowledge and technology is high, where the export market of South Australia only could be reached if the Gedong Gincu Mango come from West Java is free from the fruit fly.

\section{Fisheries}

Following the work plan of the sister province cooperation between West Java and South Australia, fisheries also become one of the sectors including in the cooperation. West Java Province has potentials in the fisheries sector, where a lot of fisheries products that could be added to the export market and become the booster for the regional economy in West Java Province. Both West Java and South Australia also would like to improve and develop the knowledge as well as the potential

28 Ibid. 
for this sector in order to enlarge the potential of this sector as well as to increase the quality for the products.

According to the work plan of sister province cooperation between West Java and South Australia, both parties would like to cooperate for the internship programs that will be given to the fisheries vocational schools graduates or for the young potential fishermen and university postgraduates from West Java to South Australia's fisheries industry. ${ }^{29}$ The program will be taken by the West Java Agency of Fisheries and Marine or Primary Industries and Regions South Australia. Regarding with the internship program, South Australia will help in bridging for West Java Province in order to propose for the internship program with several private enterprises that related with the aquaculture industry. Also, South Australia could help the internship in joining the research in aquaculture which conducts by the government of South Australia, and also the Australian Maritime and Fisheries Academy also could help in arranging for the placement for West Java students who would like to have an internship in South Australia.

Both parties also will conduct the sharing knowledge regarding the development of the aquaculture industry, including in the industry of abalone, lobster, tuna, and many other farming. The sharing knowledge will conduct in South Australia and West Java thus it makes this program will mutually beneficial. West Java Agency of Fisheries and Marine planning to conduct the house training for sharing knowledge regarding the farming of lobster. In the implementation of the work plan, West Java and South Australia had been done the sharing knowledge and technology transfer on massive development production of Abalone. ${ }^{30}$ West Java Agency for Fisheries and Maritime hosting by the PIRSA and Australian Maritime and Fisheries Academy (AMFA) get the sharing knowledge regarding how to improve the West Java Province get the detail knowledge about the practices of fisheries in South Australia in order to achieve the wealthiness of community by optimizing the potential in the fisheries and maritime sector for the development of this sector. Besides that, West Java Province also gets the knowledge transfer regarding the seed mass production, especially the detail knowledge and technology about the cultivation of Abalone. Also, more exploring for the chances to cooperate in the fisheries and maritime sector.

At the second JWGM, the Assistant for Law and Human Rights Administration West Java Regional Secretary, Achadiat Supratman, the increase of production in the fisheries and maritime sector of West Java becomes one of the focuses of the Provincial Government of West Java, comes up from the big potencies of fisheries and maritime sector in West Java. ${ }^{31}$ From the meeting it also could be known that South Australia has a good management in managing the potency of fisheries and maritime sector where one of them is in managing the cultivation of Abalone. In 2012-2013, the production of Abalone in South Australia reached 236 ton or equal with AUD 8.6 Million. ${ }^{32}$ There are two kinds of cultivation which applied by the South Australia since 2014, which are sea cage technology and benthic structures. Furthermore, West Java would like to learn about the management of fisheries sector in order to maximize the potentials which could be reached by the province.

In the implementation of this program in West Java, the agency of fisheries and maritime in West Java try to identify the

31 KJRI Sydney, "Pengembangan SDM di Bidang Kelautan dan Perikanan dan Budidaya Kerang Abalone di Jawa Barat," KJRI Sydney, 9 November 2016, accessed February 20, 2019, https://www.kemlu.go.id/ sydney/id/berita-agenda/berita-perwakilan/Pages/ Pengembangan-SDMdi-Bidang-Kelautan-PerikananBudidaya-Kerang-Abalone-di-Jabar.aspx.

32 Ibid. fisheries sector in West Java. In this program, 
facilitation which will be needed in the fisheries and maritime sector. Following with the identification, it comes up with the plan in order to fulfill the facilitation with construct the infrastructure which will be needed by the related stakeholders in West Java. Besides that, the government also planning with the parenting and domestication, as well as prepare the production of small seed for the prototype. ${ }^{33}$ Regarding with this, the government also prepare the pilot project location for develop the cultivation, where inthis step, the planning started with the establishment of location for Development and Cultivation Center of Freshwater and Sea Southern Region of West Java or as known as Balai Pengembangan Budidaya Air Payau dan Laut Wilayah Selatan (BPBAPLWS).

In response to the seriousness of West Java Province regarding the sharing knowledge and technology for the development of fisheries sector in this province, South Australia under the leading from Australian Maritime and Fisheries Academy (AMFA) do the official visit to West Java Agency of Fisheries and Maritime. In the official visit, AMFA is sharing the knowledge about the existing conditions of fisheries and maritime in West Java Province, which is including the coastline, the management of fish bidding, technology capacity as well as the human resources quality. ${ }^{34}$ At the same time, AMFA also discusses with the West Java Agency of Fisheries and Maritime regarding the internship and training program for the students from West Java in South Australia. From the discussion, AMFA got the deeper understanding about the objectives and comprehensive knowledge related with the need of West Java in doing the internship and training program. By the visit, both AMFA and West Java Agency of Fisheries and Maritime make the draft of cooperation proposal for the internship and training program.

33 Ibid. no. 27

34 Ibid. no. 27
There is a progress from the program of sister province cooperation in fisheries sector. As explain above, West Java is in the process for enlarging the potential of its fisheries sector, especially in the Abalone cultivation. The sharing knowledge and technology transfer from AMFA to the fisheries sector in West Java Province is very beneficial and useful which this is very important for the development of fisheries sector of West Java and it could support and give suggestion for the betterment of fisheries sector in this province. Furthermore, West Java Agency of Fisheries and Maritime could prepare for the facilitation as well as the construction of infrastructure which will support the better development of fisheries sector in West Java. The result of the program could be seen if the West Java Province is put attention about the result that could be reach by implementing the knowledge that had been share by AMFA. Moreover, the fisheries products from West Java also could entry the export with a better quality, thus it will make more country that will be attracted by the fisheries products of West Java Province.

However, according to all the programs in fisheries sector which been set in the work plan of sister province cooperation between West Java and South Australia, the internship and training program for the students of West Java in South Australia still cannot be proceed because of the lack of fund that faced by the West Java Province. The government still finding for the sponsor or the third party who would like to sponsor the funding for the internship and training program.

\section{Tourism, including culture and education}

Tourism is also one of the sectors which include in the sister province cooperation between West Java and South Australia. The including of the tourism sector in the cooperation, also makes culture and education 
become the part in the cooperation. For them, those sectors have potentials in enlarging the mutual beneficial for both region. At the same time, West Java also has potentials in the tourism, culture, and education sector. West Java has a lot of tourism destinations, which those could be beneficial for the economic region. With the maximal efforts do by the Tourism and Culture Agency of West Java, a lot of tourism will be attracted by the tourist.

In the sister province cooperation between West Java and South Australia, the Provincial Government of West Java put tourism, including the culture and education as one of the sectors which cooperated in the cooperation in order to improve and develop the potentials in this sector. According to the work plan which been set for the tourism sector in the cooperation, there are several programs that setting by the Joint Working Group, where both region could gain the mutual benefit for this sector by doing the programs in the cooperation..$^{35}$ For the tourism and culture sector, West Java and South Australia using the two way in promoting and facilitating the tourism sector, which consists with the discussion of both parties in agreed regarding the activities that lead to the two-way tourism promotion and cooperation, and also the exchanges of arts and culture. The cooperation intourism sector is under the responsibility of the West Java Agency of Tourism and Culture and South Australia Tourism Commission. At the same time, West Java and South Australia also agreed to do the collaboration program of Department for Education and Child Development (DECD), Flinders University, and Indonesian Government where they will make House of Culture or Rumah Budaya in South Australia.

In the education sector, there is also collaboration program for the primary, secondary, vocational and tertiary level. The collaboration also included the exchange of 35 Ibid. no. 27 students and teachers, where the programs are under the responsibility and collaboration of West Java Agency of Education and South Australia Department for Education and Child Development, as well as Indonesian Minister for Education and Culture and South Australian Minister for Education and Child Development (MECD). For this program, there will be sister school relationships and support in South Australia where it corporates for the teaching of Indonesian language in South Australian government schools. At the same time, also including the proposed advisor for the Indonesian language and culture in order to support the teachers of Indonesian language and culture in South Australian schools within the proposed $\mathrm{MoU}$ of Indonesia and MECD.

On theother hand, the Australian Indonesian Association also participates in the sister school relationship between West Java and South Australia. In here, there is INDOfest schools program where the purpose of this program is for the development and also the presentation regarding the language and cultural activities by students of Indonesian in South Australia. Besides that, there will also a professional training for the West Javanese teacher and tutor in South Australia, where teachers from DEDC will participate in the exchanges program to Indonesian schools. The purpose of the exchange program is for DEDC teachers to learn about the Indonesian curriculum as well as the local educational culture. From the program, the teachers of DEDC expected to develop and maintain the Indonesian language proficiency. For the Indonesian teachers, they will do the exchange program to the South Australian schools. Same with the DEDC teachers, the Indonesian teachers also will cooperate with the South Australian teachers and experience regarding the Australian Curriculum. Not only teacher exchange, the students to and from Indonesia also will do the exchange program. 
Same with the teacher exchange program, the students from West Java will do the exchange program to South Australia and the students from South Australia will do the exchange program to West Java. The aimed of this program is to make every student of West Java and South Australia learn about the language and culture of both countries.

West Java Agency of Education also proposes to implement one of the education program from South Australia, which is Reading Challenge Program. The program is also known as the exchange in encouraging the interest of students in reading. Moreover, there also a short course in South Australia for the Bankers from West Java. For the short course, it will be under the responsible from West Java PT Bank Jabar Banten with the South Australian Department of State Development. In here, South Australian Department of State Development will facilitate the delegations of Bankers from West Java in negotiating with the education institution in South Australia which related with the program. At the same time, there is also a program of education, internship, and work placement for the nursing and midwifery from West Java students to South Australia. For this, West Java Agency of Health and South Australian Department of State Development will responsible for the program. Same with the short course for Bankers, the South Australian Department of State Development also facilitating with the related education institution in South Australia.

In the implementation of the programs for tourism, culture and education sector, there are several programs which had been done by West Java and South Australia. First, West Java participates in arts and culture exchange in the OzAsia Festival 2015. ${ }^{36}$ At this program,

36 Nograhany Widhi Koesmawardhani, "OzAsia Festival 2015: Melihat Indonesia yang Bukan Cuma Bali," Detik News.com, 26 September 2015, accessed February 20, 2019, https://news.detik.com/berita/d-3028554/ ozasia-festival-2015-melihat-indonesia-yang-bukancuma-bali.
West Java under the responsibility of West Java Agency of Tourism and Culture introduces the traditional art from West Java to the public in South Australia. OzAsia Festival is the biggest annual event of art and culture in Adelaide, South Australia. The event could be a strategic way for West Java in promoting the traditional art and culture of West Java. Contemporary Music of Sambasunda, performance of traditional games of West Java by Hong Community, and the exhibition of Cirebon Mask, as well as the Topeng Dance from Cirebon, are the performances that performed in the event, where those performances got the positive enthusiasm from the audiences. ${ }^{37}$ By the participation of West Java's traditional art and culture in OzAsia Festival, it makes several event organizers in South Australia which offer to perform the traditional art and culture of West Java in South Australia's event.

There is also an internship and training program in South Australia for the Art Manager and Event Organizer from West Java. The program is hosting by the Adelaide Festival Center Trust. From the internship and training program, there are several results which could be gain by the delegates of the program from West Java. At first, the program improves the capacity of Art Manager and Event Organizer in West Java in achieving the mission for West Java Province to become as the Festival Province in Indonesia. Besides that, the training gives knowledges for the Art Manager to become the Event Organizer for the festivals or events which held by West Java Province. The program is coming from the offers which offered by several Event Organizers in South Australia who want to put the performance of traditional art and culture of West Java in South Australia's events.

On the other hand, there is also an internship and training program for the Teachers and Principals from West Java Province. West Java Agency of Education is 37 Ibid. 
responsible for the program. Hosting by the DEDC, the internship and training program give a lot of feedback and knowledge for the teachers as well as the principals in develop the education system in West Java Province. By the program, it improves not only the knowledge but also the global knowledge and professionalism of West Java's teachers and principals, where it expected could be implemented and improve the education system in the West Javanese schools. From this program also could become the beginning for the establishment of West Java Leader's Reading Challenge (WJLRC) where it could help the literacy of South Australia's movement in West Java Province. ${ }^{38}$ As the implementation of the internship and training program in West Javanese schools, most of them are getting better in the management system where the schools are become more professional in doing their duties as the education institution. ${ }^{39}$ Moreover, most of the schools also change from teacher centered to student centered. ${ }^{40}$ Also, the program becomes the establishment of literacy of South Australia's movement in West Java, where the WJLRC is massive and adaptable in the education environment of West Java. ${ }^{41}$

Following with the literacy of South Australia's movement in West Java, the WJLRC started to introduce by the West Javanese schools to the West Javanese students. The movement is massively promoted in the community of West Javanese students, as well as the West Javanese students. At the same time, the movement also expected to build up the potency of young generation in West Java in authoring the friendship of West Java and South Australia. In the implementing 38 Ibid. no. 27

39 Ibid. no. 27

40 Ibid. no. 27

41 Dinas Pendidikan Provinsi Jawa Barat, "Kilasan Sejaran West Java Leader's Reading Challenge," Gerakan Literasi Sekolah Dinas Pendidikan Provinsi Jawa Barat, 2016, accessed February 20, 2019, http://literasi. jabarprov.go.id/index.php?class=sejarah. of the movement in West Java, there will be a medal exchange program from the West Java Governor and also the Premier of South Australia as the award for the participants. Other than that, there is also a book published, where the book is written jointly by the West Java and South Australian students who are participated in the program. Also, there is camp or jamboree which held in West Java as the frame of WJLRC program.

Moreover, there is also the internship program in West Java for the South Australian teachers who teach the Bahasa Indonesia subject. By the internship program, the South Australian teacher expected to gain a better knowledge regarding the subject of Bahasa Indonesia as well as the West Java culture. After the internship program in West Java, the South Australian teachers could bring the positive impacts to the students in South Australia, as well as to more familiarize the West Java culture and also the Indonesian culture by teaching and learning about the Indonesian language. In the program, the South Australian teachers got the placement for two years in the West Javanese schools for get a better understanding and develop their knowledge regarding the culture of West Java and Indonesia as well as the Indonesian language.

Therefore, from the progress of the sister province between West Java and South Australia, it could be seen that the cooperation could be more beneficial for both regions. In order to maximize the potentials of this cooperation, both regions could be more intense in doing the communication regarding the programs as well as the progress of the running program in the cooperation. Furthermore, the responsible parties from both regions also could be more focus on the programs which had been set before. The cooperation also could closer not only the government to government relationship, 
but also the people to people relationship. In here, both governments should be more facilitate to enlarge the relationship between West Javanese with South Australians, as well as involving them in the running of the cooperation.

\section{Conclusion}

From the explanations above, it could be seen how the practice of Indonesia's para-diplomacy towards the sister province of West Java and South Australia. Through the implementation of the work plan in the sister province, it shows that there are still a lot of opportunities and benefits which could be gain by both regions. The Joint Working Group could discuss more in order to running the programs which still delayed, and for the programs which in running could be more intense for maximizing the benefits for both regions.

From the analysis of the progress of the sister province cooperation between West Java and South Australia, there are several challenges and struggles which faced by both regions. One of the struggles is the lack of communication. As could be seen from the progress of the programs in the cooperation, it could be seen some of the programs are cannot be running because of both regions that lack communication with each other. Moreover, the role of the person in charge also become an important parts to smooth the running of the cooperation. To develop the progress of the cooperation, the person in charge should be focus and maintain the communication with the partner in order to progressing the programs which had been set before.

The result of the para-diplomacy cannot be the same from one region to another region. Every sub-national government who cooperate with foreign parties will have a different result and benefit which gain from the cooperation itself. Even though the case of para-diplomacy of a region is similar with the case of para-diplomacy from another region, but the implementation as well as the result probably different one with another. Every region has their own goals in doing the cooperation. At the same time, the different partner in the cooperation also cause to the different process and implementation of paradiplomacy. In doing the cooperation, both local and foreign parties have their own rules and regulation as well as goals which would be reached through the cooperation. Other than the governmental role, the people to people role also giver a different result of paradiplomacy. The people to people relationship also have a role in the cooperation where it could help the development as well as the progress of the cooperation. Thus, it cause the different result of para-diplomacy in every subnational government.

Therefore, the implementation of sister province cooperation between West Java and South Australia is still developing, where with the remaining time of the period of cooperation it expected could be more develop and give more progress to the cooperation. Both West Java and South Australia still need cooperate each other as well as maintain the relations in order to implementing the work plan which had been set before. From 2015 to 2017, the cooperation has given a good progress for the beginning of the cooperation through the progress of some programs in the work plan. Within more focus and effort in doing and implementing the cooperation, it could be a mutually beneficial cooperation for both West Java and South Australia, where within times both parties could gain the benefit from the cooperation. While the cooperation is still running until 2020, therefore there is still many opportunities for both parties in developing and increasing the potentials in the cooperation. 


\section{REFERENCES}

Agustina, Astri. Pengembangan pariwisata di Jawa Barat belum maksimal. August 1, 2018. https://bandung.merdeka.com/ pariwisata/pengembangan-pariwisata-dijawa-barat-belum-maksimal-180801t.html (accessed February 20, 2019).

Australia, Government West Java \& South. Memorandum of Understanding Between the Government of West Java Province of the Republic of Indonesia and The Crown in Right of the State of South Australia Concerning Sister Province - State Cooperation. Adelaide, South Australia, September 24, 2015.

Barat, Dinas Pendidikan Provinsi Jawa. Kilasan Sejarah West Java Leader's Reading Challenge. 2016. http://literasi.jabarprov. go.id/index.php?class=sejarah (accessed February 20, 2019).

Barat, Pemerintah Provinsi Jawa. 6 Misi Tingkatkan Kualitas Pendidikan. March 29, 2017. http://www.jabarprov.go.id/index. php/news/22180/2017/03/29/6-MisiTingkatkan-Kualitas-Pendidikan (accessed February 20, 2019).

-. Potensi Seni dan Budaya Jawa Barat. 2006. http://www.jabarprov.go.id/index.php/ potensi_daerah/detail/20/4 (accessed February 20, 2019).

Basa, Guzrizal Dt Salubuak. Bridging the Gap Between Indonesia and Australia. May 28, 2018. https://www.internationalaffairs. org.au/australianoutlook/bridging-thegap-between-indonesia-and-australia/ (accessed February 20, 2019).

Department of Foreign Affairs and Trade, Australian Government. Joint Declaration on a Comprehensive Strategic Partnership between Australia and the Republic of Indonesia. August 31, 2018. https://
dfat.gov.au/geo/indonesia/Pages/jointdeclaration-comprehensive-strategicpartnership-between-the-commonwealthof-australia-and-republic-of-indonesia.aspx (accessed February 20, 2019).

Direktorat Perjanjian Ekonomi dan SosialBudaya. Panduan Umum Tata Cara Hubungan dan Kerjasama Luar Negeri oleh Pemerintah Daerah. Jakarta, 2006.

Indonesia, Kementerian Sekretariat Negara Republik. Undang-Undang Republik Indonesia Nomor 22 Tahun 1999. Jakarta, May 7, 1999.

Istiqomah, Zuli. Jabar Potensi Kedaulatan Pangan Nasional. January 23, 2017. https://www.republika.co.id/berita/ nasional/daerah/17/01/22/ok6nwg370jabar-potensi-kedaulatan-pangan-nasional (accessed February 20, 2019).

Koesmawardhani, Nograhany Widhi. OzAsia Festival 2015: Melihat Indonesia yang Bukan Cuma Bali. September 26, 2015. https:// news.detik.com/berita/d-3028554/ozasiafestival-2015-melihat-indonesia-yangbukan-cuma-bali (accessed February 20, 2019).

Kooistra, Marten. Paradiplomacy in Practise: The Development of Paradiplomacy in Quebec, Scotland, and California. 2017.

Lecours, Andre. Political Issues of Paradiplomacy: Lessons from the Developed World. Netherlands Institute of International Relations 'Clingendael', 2008.

Minami, Masaki. "The Role and Policy of the South Australian Government in the Development of Economic Ties with Asian Nations." Adelaide, 1997.

Mukti, Takdir Ali. Paradiplomacy: Kerjasama Luar Negeri oleh Pemda di Indonesia. Yogyakarta: The Phinisi Press Yogyakarta, 2013. 
Province, Governmental and Cooperation Bureau of West Java. "Achievement of the Implementation Sister Province - State Coorperation between West Java and South Australia." Bandung, 2017.

Putra, Yudha Manggala P. Mangga 'Gedong Gincu' Diminati Pasar Timur Tengah. May 5, 2014. https://www.republika.co.id/berita/ nasional/jawa-barat-nasional/14/05/05/ n53 prj-mangga-gedong-gincu-diminatipasar-timur-tengah (accessed February 20, 2019).

Saha, Rakhahari Chatterji and Swagata. "Paradiplomacy: Concept and the Context." India Quaterly, 2017: 375-384.

Sydney, KJRI. Pengembangan SDM di Bidang Kelautan dan Perikanan dan Budidaya Kerang Abalone di Jawa Barat. November 9, 2016. https://www.kemlu.go.id/sydney/id/ berita-agenda/berita-perwakilan/Pages/ Pengembangan-SDMdi-Bidang-KelautanPerikanan-Budidaya-Kerang-Abalone-diJabar.aspx (accessed February 20, 2019).

-. Signing of $\mathrm{MoU}$ on Sister Province / State Cooperation between West Java and South Australia. September 24, 2015. https:// www.kemlu.go.id/sydney/en/beritaagenda/berita-perwakilan/Pages/ Signing-of-MoU-on-Sister-Province-StateCooperation-between-West-Java-andSouth-Australia.aspx (accessed February 20, 2019).

Tavares, Rodrigo. Paradiplomacy: Cities and States as Global Players. New York: Oxford University Press, 2016.

Tempo.co. Deddy Mizwar: Potensi Perikanan Jabar Belum Optimal. December 17, 2017.https:// nasional.tempo.co/read/1043043/deddymizwar-potensi-perikanan-jabar-belumoptimal (accessed February 20, 2019). 